\title{
Toxicity of Uranium Adsorbent Materials using the Microtox Toxicity Test
}

DOE-NE Milestone Report M3FT-15PN0310056
Jiyeon Park
Robert Jeters
Gary Gill
Li-Jung Kuo
George Bonheyo

October 2014

Pacific Northwest

NATIONAL LABORATORY

Proudly Operated by Battelle Since 1965 


\title{
DISCLAIMER
}

This report was prepared as an account of work sponsored by an agency of the United States Government. Neither the United States Government nor any agency thereof, nor Battelle Memorial Institute, nor any of their employees, makes any warranty, express or implied, or assumes any legal liability or responsibility for the accuracy, completeness, or usefulness of any information, apparatus, product, or process disclosed, or represents that its use would not infringe privately owned rights. Reference herein to any specific commercial product, process, or service by trade name, trademark, manufacturer, or otherwise does not necessarily constitute or imply its endorsement, recommendation, or favoring by the United States Government or any agency thereof, or Battelle Memorial Institute. The views and opinions of authors expressed herein do not necessarily state or reflect those of the United States Govermment or any agency thereof.

\author{
PACIFIC NORTHWEST NATIONAL LABORATORY \\ operated by \\ BATTELLE \\ for the \\ UNITED STATES DEPARTMENT OF ENERGY \\ under Contract DE-AC05-76RLO1830
}

Printed in the United States of America

Available to DOE and DOE contractors from the Omec of Scientific and Techinical Information.

P.O. Box 62, Oak Ridge, TN 37831-0062:

ph: (865) 576-8401

fax: (865) 576-5728

email: reports a adonis,osti-gov

Avallable to the public from the National Techaical Information Service

5301 Shaw nee Rd., Alexandria, VA 22312

ph: (800) \$53-NTIS (6847)

email: ordersintis, gov <http://www.ntis.gov/about/form.asps $>$

Onliac ordering: http://www.ntis.gov 


\section{Toxicity of Uranium Adsorbent Materials using the Microtox Toxicity Test}

DOE-NE Milestone Report M3FT-15PN0310056

Jiyeon Park, Robert Jeters, Gary Gill, Li-Jung Kuo, and George Bonheyo

Marine Sciences Laboratory

Pacific Northwest National Laboratory

1529 W. Sequim Bay Road

Sequim, WA 98382

October 2014

Prepared for

the U.S. Department of Energy

under Contract DE-AC05-76RL01830

Pacific Northwest National Laboratory

Richland, Washington 99352 



\section{Executive Summary}

The Marine Sciences Laboratory at the Pacific Northwest National Laboratory evaluated the toxicity of a diverse range of natural and synthetic materials used to extract uranium from seawater. The uranium adsorbent materials are being developed as part of the U. S. Department of Energy, Office of Nuclear Energy, Fuel Resources Program. The goal of this effort was to identify whether deployment of a farm of these materials into the marine environment would have any toxic effects on marine organisms. Toxicity was evaluated using the well-recognized and accepted Microtox ${ }^{\circledR}$ toxicity test. The Microtox ${ }^{\circledR}$ assay uses a microorganism found in seawater that is susceptible to a wide range of toxins. This established toxicity assay is quick, reliable and cost-efficient.

Direct contact with 5 out of 10 adsorbents were toxic (reached EC50), but only when the adsorbent material was at very high concentrations. No toxicity was observed with seawater that was in contact with the absorbent material from 63 different adsorbent materials. Based on testing to date, there does not appear to be any significant concerns with toxicity of adsorbent materials; Extraction from seawater could be performed with minimal impact to marine environment. 



\section{Materials and Methods}

The toxicity of adsorbent materials were evaluated using the Microtox ${ }^{\circledR}$ assay to determine if the supplied adsorbent materials and seawater effluent from uranium extraction columns have any toxic effects on marine organisms, The assay measures the luminescence of the bioluminescent marine bacterium Aliivibrio fischeri (ATCC 49387), an indicator of metabolism in the organism, after a 30minute (1) exposure to the sample material. The Microtox ${ }^{\circledR}$ assay is a useful tool to evaluate the toxicity of a wide range of metals $(2,3)$ and organic $(4,5)$ compounds that are either in liquid or solid phase. In addition, the Microtox ${ }^{\circledR}$ test is low-cost and easy to operate and has a long history of use for determining toxicity in environmental samples (6-8). The Advanced Monitoring Systems (AMS) Center that is part of the Environmental Technology Verification (ETV) Program has evaluated, tested and validated the Microtox ${ }^{\circledR}$ assay for assessing various contaminants in water samples. The ETV is supported by the U.S. Environmental Protection Agency (EPA) (9). The Microtox ${ }^{\circledR}$ assay has also been used by U.S. Geological Survey and National Oceanic and Atmospheric Administration (NOAA) to assay sediment from the Delaware Bay and surrounding areas for toxicity (10).

Aliivibrio fischeri culture was grown overnight in ALNa Broth (1) at $22^{\circ} \mathrm{C}$ with vigorous shaking. The overnight culture was used to inoculate $10 \mathrm{ml}$ of ALNa broth, and the culture was incubated with vigorous shaking at $22^{\circ} \mathrm{C}$. Cells were grown until the optical density at $590 \mathrm{~nm}\left(\mathrm{OD}_{590}\right)$ was 0.25 . Cells were harvested by centrifugation at $4150 \mathrm{rpm}$ for $5 \mathrm{~min}$ followed by washing in $10 \mathrm{ml} 3 \% \mathrm{NaCl} ; \mathrm{pH}$ 7. Cells were then resuspended in $10 \mathrm{~mL} 3 \% \mathrm{NaCl}$ at $\mathrm{pH}$ 7. The cell suspension was mixed with test materials for 30 minutes, and the luminescence was measured using a Synergy HT microplate reader (Biotek, Winooski, VT, USA).

The decrease in bacterial luminescence (INH\%) (11) was calculated as shown below. If the luminescence decreased more than $50 \%$ after exposure to sample materials for 30 minutes, the concentration of toxicant is designated as the effective concentration $\left(\mathrm{EC}_{50}\right)(11)$. Values obtained with cells only control sample (suspended in $3 \% \mathrm{NaCl}$ or seawater) was set to $100 \%$, and the luminescence of each sample was represented as a percentage of cells only value. $\mathrm{ZnSO}_{4}(12)$ was used as control toxicant $\left(0.625,1.25,2.5\right.$, and $5 \mu \mathrm{g} / \mathrm{mL}$ to validate the Microtox ${ }^{\circledR}$ assay results.

\section{The decrease in bacterial luminescence (INH\%)}

$$
\begin{gathered}
\mathrm{INH} \%=100-\left(\frac{\mathrm{IT} T}{\mathrm{IT} 0 \times \mathrm{KF}}\right) \times 100 \\
\mathrm{KF}=\frac{\mathrm{IC} T}{\mathrm{IC} 0}
\end{gathered}
$$

IC0: luminescence of control at $t=0$

ICT: luminescence of control after ' $T$ ' minutes exposure time

IT0: luminescence of test sample at $\mathrm{t}=0$

ITT: luminescence of test sample after ' $T$ ' minutes exposure time

KF: correction factor based on the control/blank

A positive response means a decrease in luminescence, while a negative response means the luminescence increased.

\section{EC50 (50\% Effective Concentration)}

The concentration of the toxicant $(\mathrm{mg} / \mathrm{L})$ that causes a $50 \%$ reduction in light after exposure for ' $T$ ' minutes 


\section{Results and Discussion}

\section{Toxicity of adsorbent materials via direct contact}

Supplied adsorbent materials were tested for direct contact toxicity using increased concentrations. Due to limited number of adsorbent materials currently available, only 10 samples were tested, and hence the results for direct testing should be considered preliminary.

1) Oak Ridge National Laboratory (Richard Mayes)

- $\mathrm{YF} 130313 \mathrm{C} \mathrm{KOH}$ Condition did not have an $\mathrm{EC}_{50}$ up to $25 \% \mathrm{v} / \mathrm{v}$.

- YF130226C Copolymer-PAN had an $\mathrm{EC}_{50}$ at $25 \mathrm{mg} / \mathrm{ml}$.

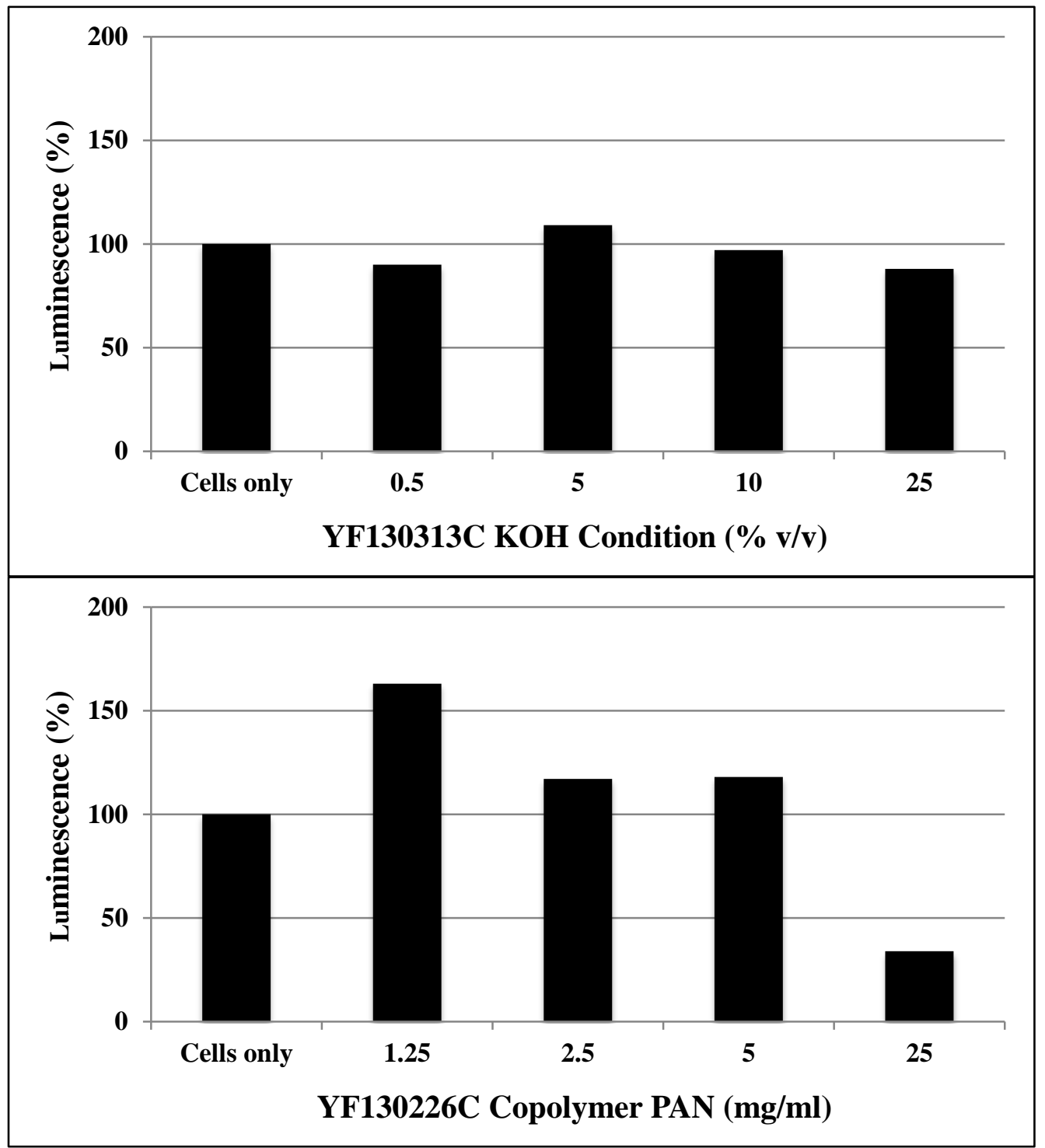

- The Microtox ${ }^{\circledR}$ assays on YF130313C KOH Condition and YF130226C CopolymerPAN were done one time due to the limited amount of supplied sample materials. 
2) University of North Carolina (Carter Abney/Lin group)

- CA-4139: Porous Titanium Dioxide had an $\mathrm{EC}_{50}$ at $1.1 \mathrm{mg} / \mathrm{ml}$.

- CA-4149: Porous Titanium Phosphate did not have an $\mathrm{EC}_{50}$ up to $6.4 \mathrm{mg} / \mathrm{ml}$.

- MC-Precursor Unfunctionalized Mesoporous Carbon did not have an $\mathrm{EC}_{50}$ up to $10 \mathrm{mg} / \mathrm{ml}$.

- MC-Phosphate (612) Phosphoryl-functionalized Mesoporous Carbon had an $\mathrm{EC}_{50}$ at $5 \mathrm{mg} / \mathrm{ml}$.

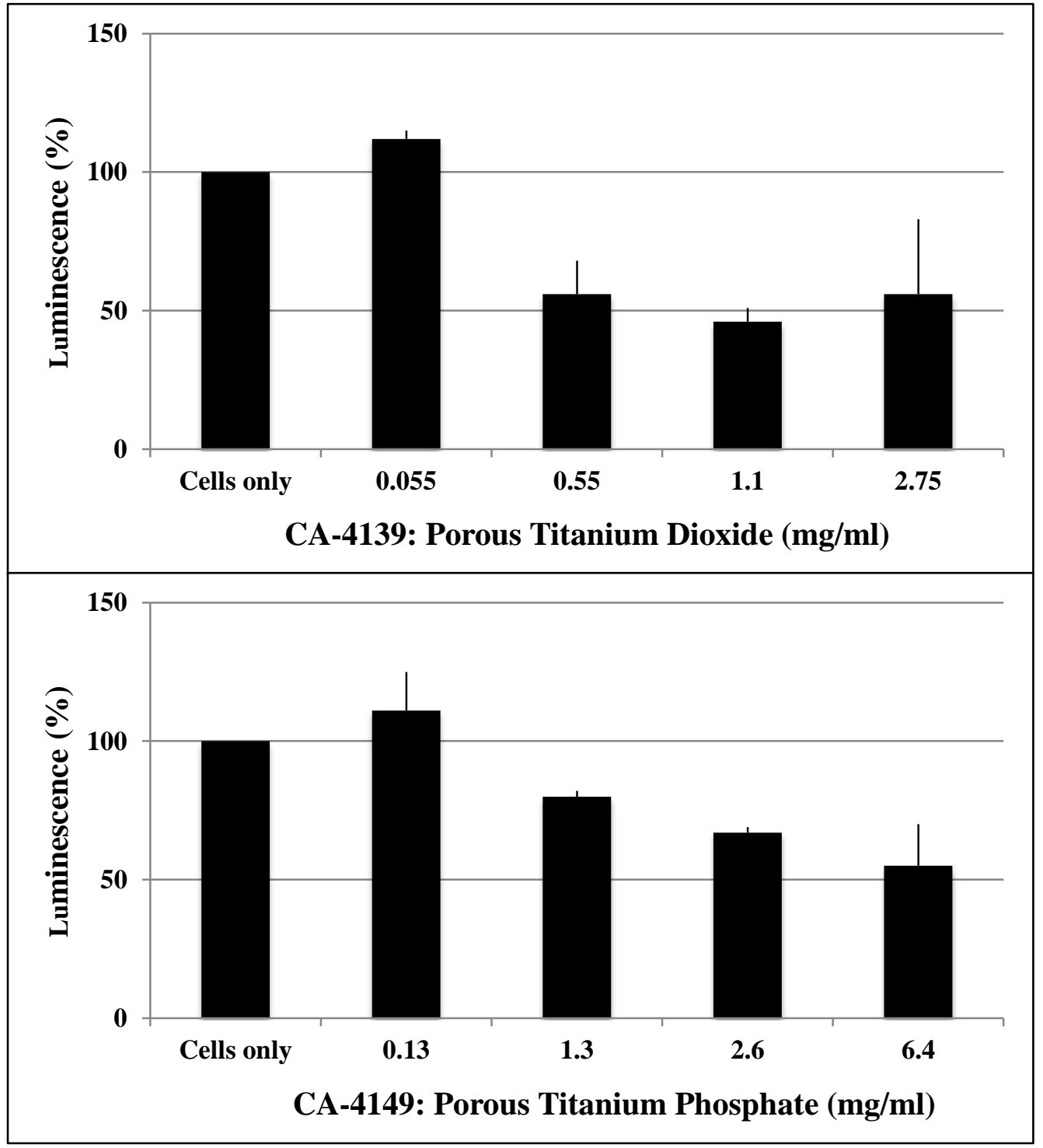

- CA-4139: Porous Titanium Dioxide and CA-4149: Porous Titanium Phosphate were tested in duplicated experiments. Graphs show the mean value and standard deviation is shown as error bars. 


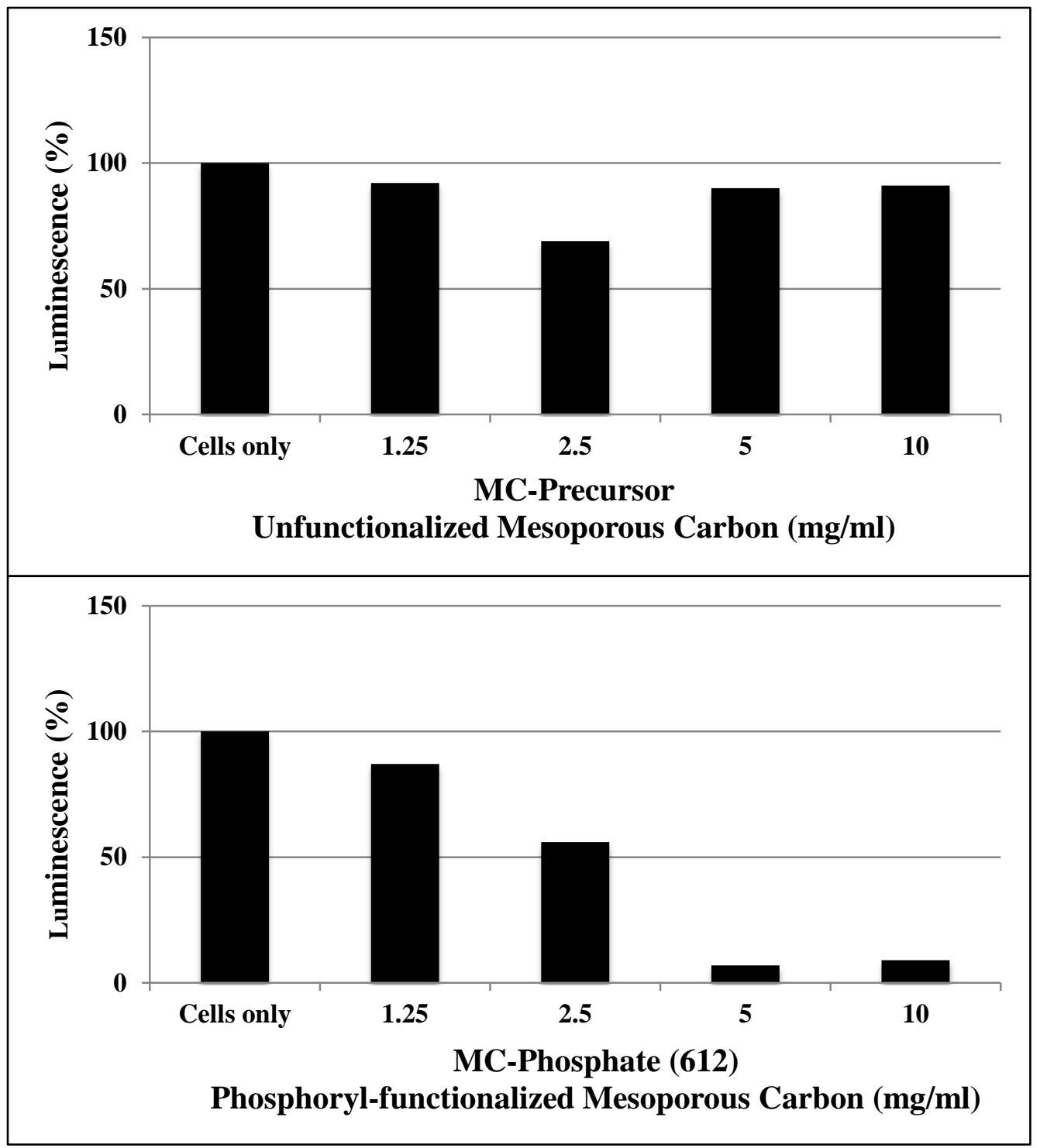

- The Microtox® assays on MC-Precursor Unfunctionalized Mesoporous Carbon and MCPhosphate Phosphoryl-functionalized Mesoporous Carbon were done one time due to the limited amount of supplied sample materials.

3) Chinese Academy of Science

- UHMWPE-g-PAPA-co-PAO \#1 had an $\mathrm{EC}_{50}$ at $0.625 \mathrm{mg} / \mathrm{ml}$.

- UHMWPE-g-PAPA-co-PAO \#2 had an $\mathrm{EC}_{50}$ up to $0.3125 \mathrm{mg} / \mathrm{ml}$.

- UHMWPE-g-PAPA-co-PAO \#3 did not have an $\mathrm{EC}_{50}$ up to $2.5 \mathrm{mg} / \mathrm{ml}$.

- UHMWPE-g-PAPA-co-PAO \#4 did not have an $\mathrm{EC}_{50}$ up to $2.5 \mathrm{mg} / \mathrm{ml}$.

All fiber types 1 4 were tested in triplicate. Graphs show the mean value and standard deviation is shown as error bars. 


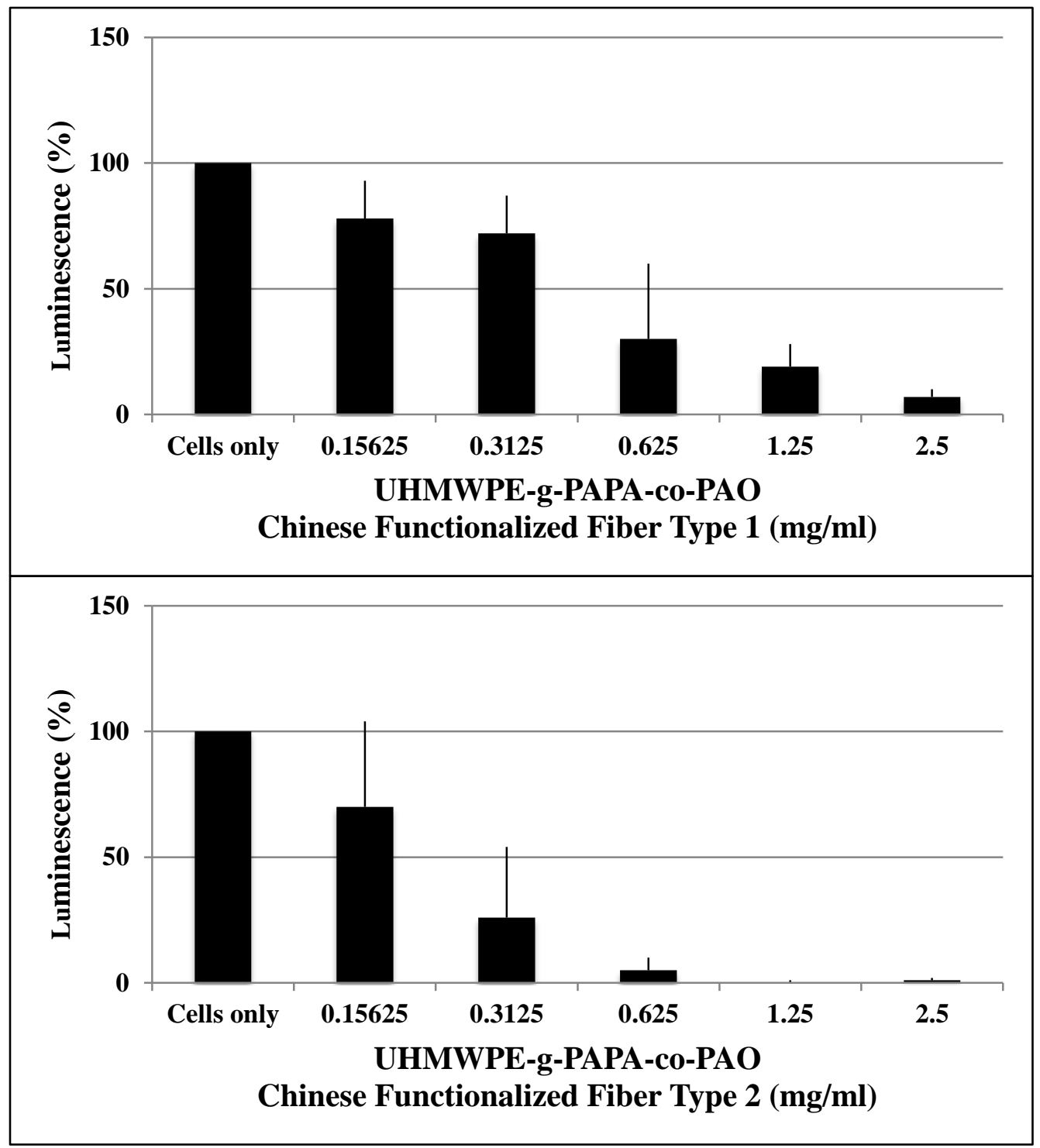




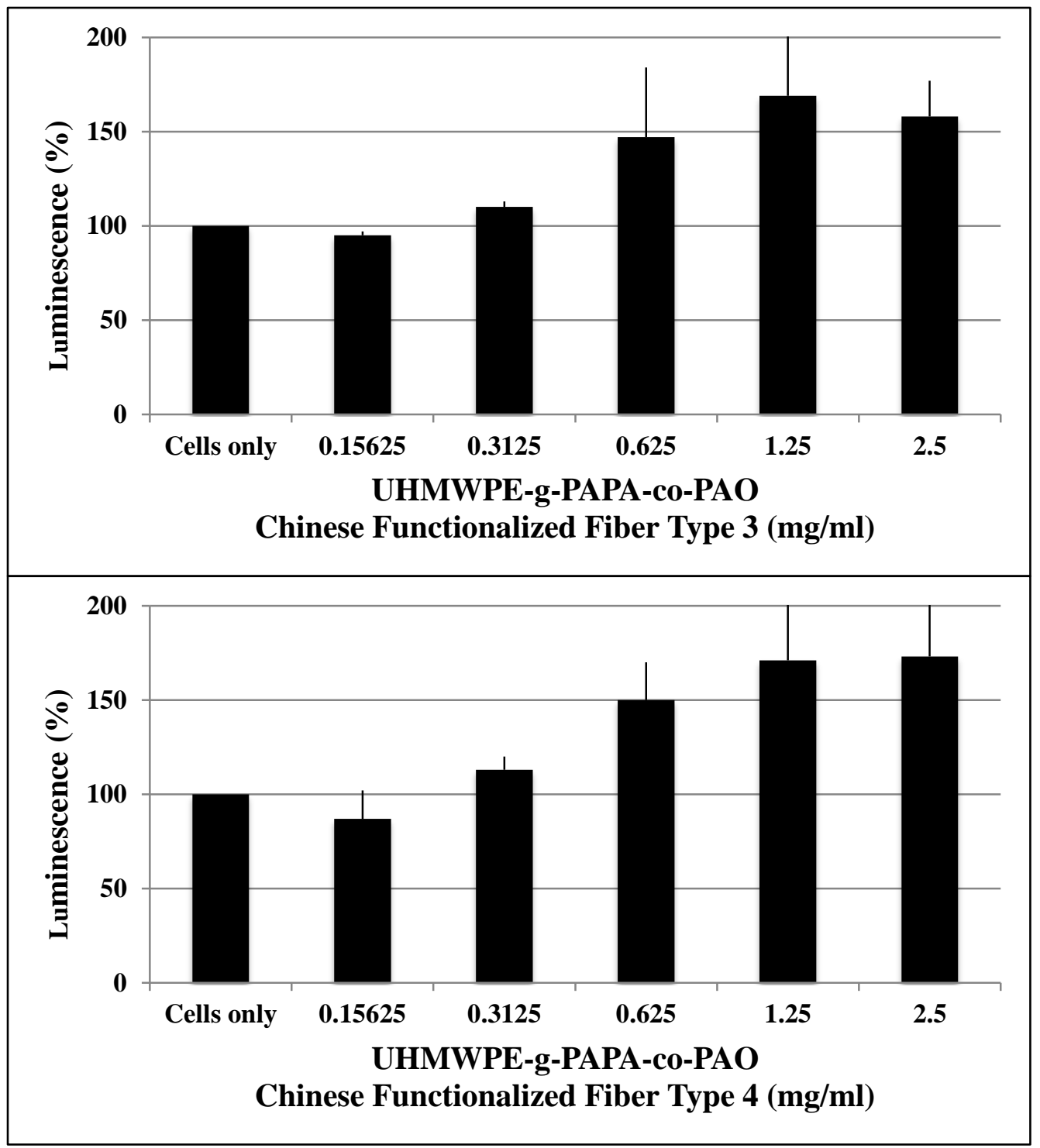

- UHMWPE-g-PAPA-co-PAO Chinese Functionalized Fiber Type 3 and 4 showed no signs of toxicity. Increase in luminescence is likely due to compound present on functionalized fiber. Some select compounds have been shown to increase luminescence at high concentrations. 


\section{Toxicity of seawater effluent collected from uranium extraction columns}

Toxicity was evaluated in seawater that passed through columns containing adsorbent materials (effluent test). The Microtox ${ }^{\circledR}$ assay was performed with increasing amounts of seawater effluent up to $75 \% \mathrm{v} / \mathrm{v}$ because a minimum amount of Aliivibrio fischeri cells were required to measure luminescence. None of seawater effluent samples had an $\mathrm{EC}_{50}$. The experiments were done in triplicate. Mean values are shown and standard deviations are indicated as error bars.

1) Oak Ridge National Laboratory

- 38H21: 3 days

- TSU 20A: 1 week

- Costas Fiber: 8 weeks
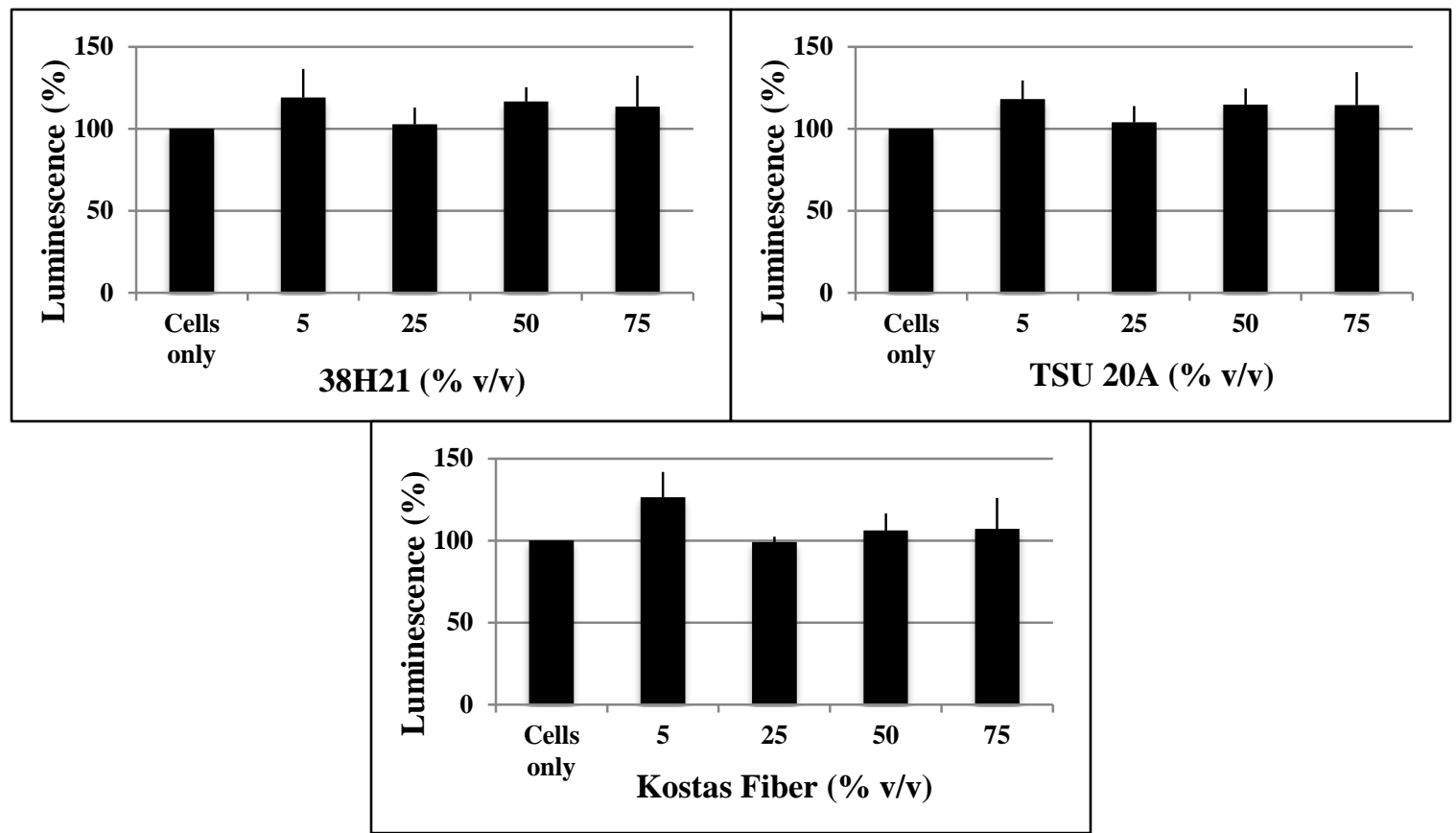

2) Japan

- Japan 2010: 3 days

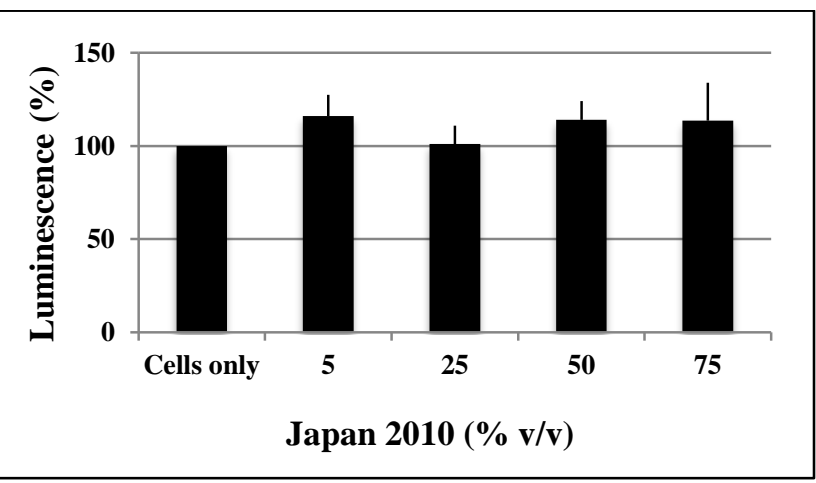

3) University of Alabama 
- AO Fiber: 6 weeks

- DA Fiber: 6 weeks

- SS Fiber: 6 weeks
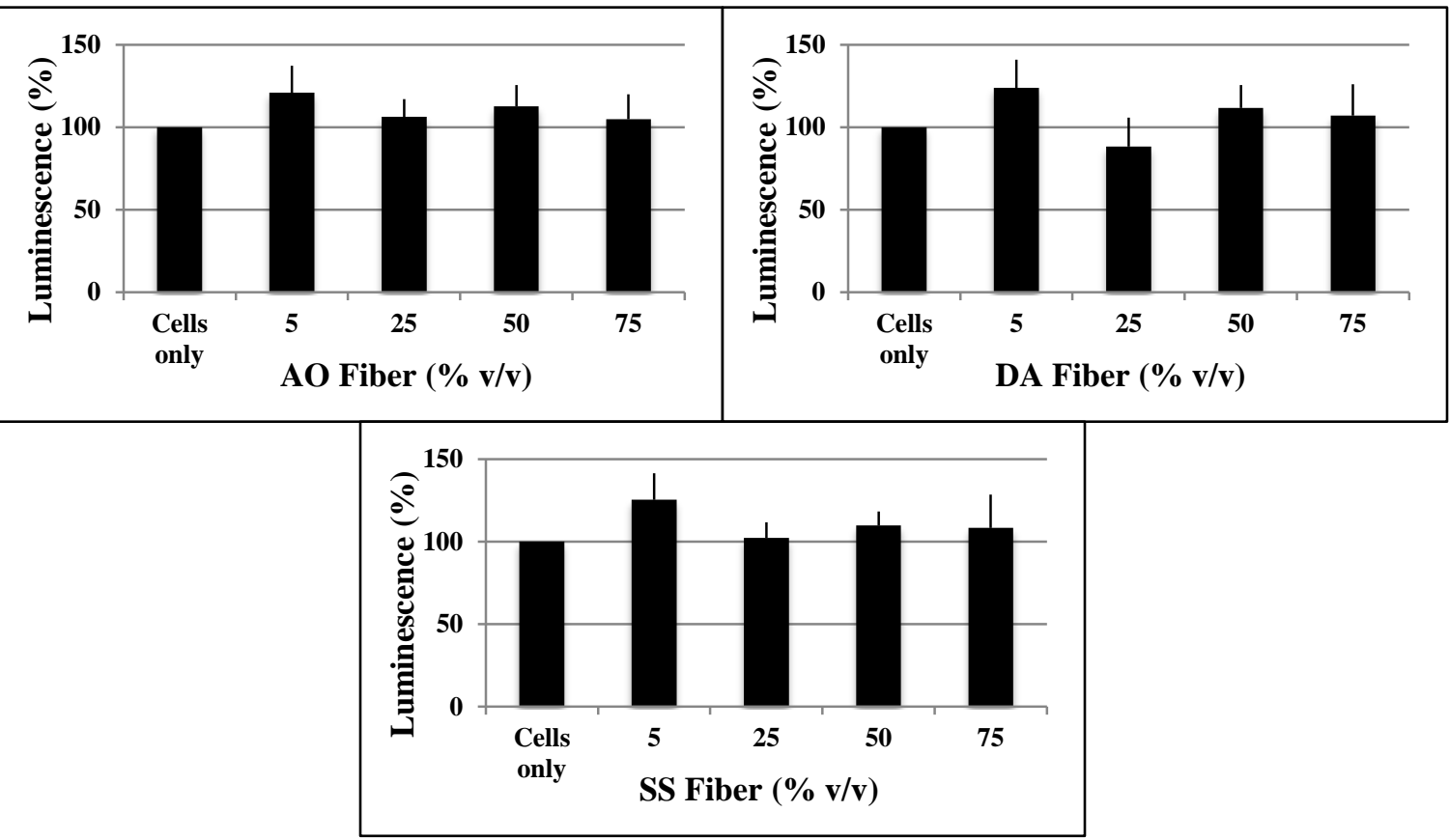

4) Chinese Academy of Science

- Chinese Fiber \#2: 3 days

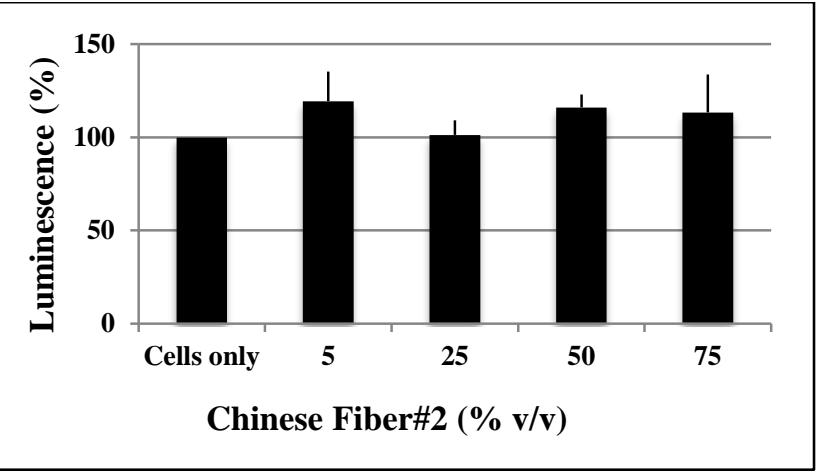

\section{Time-course experiments to determine toxicity of seawater effluent collected from uranium extraction columns}

In order to determine whether a longer exposure of the adsorbent to seawater could have toxic effects on marine organisms, time-course experiments were done on seawater effluents samples that were in contact with 55 different adsorbent materials. Seawater effluent samples were collected at three different time points; 1 hour, 1 day, and 1 week after exposure to adsorbent materials in uranium uptake columns. Samples up to $75 \% \mathrm{v} / \mathrm{v}$ were tested in order to measure luminescence from Allivibrio fischeri to 
evaluate toxicity of the sample. Three independent experiments were done on these samples, and all samples up to $75 \% \mathrm{v} / \mathrm{v}$ did not have an $\mathrm{EC}_{50}$. The experiments were done in triplicate Mean values are shown and standard deviations are indicated as error bars.

1) Oak Ridge National Laboratory (42 adsorbents)

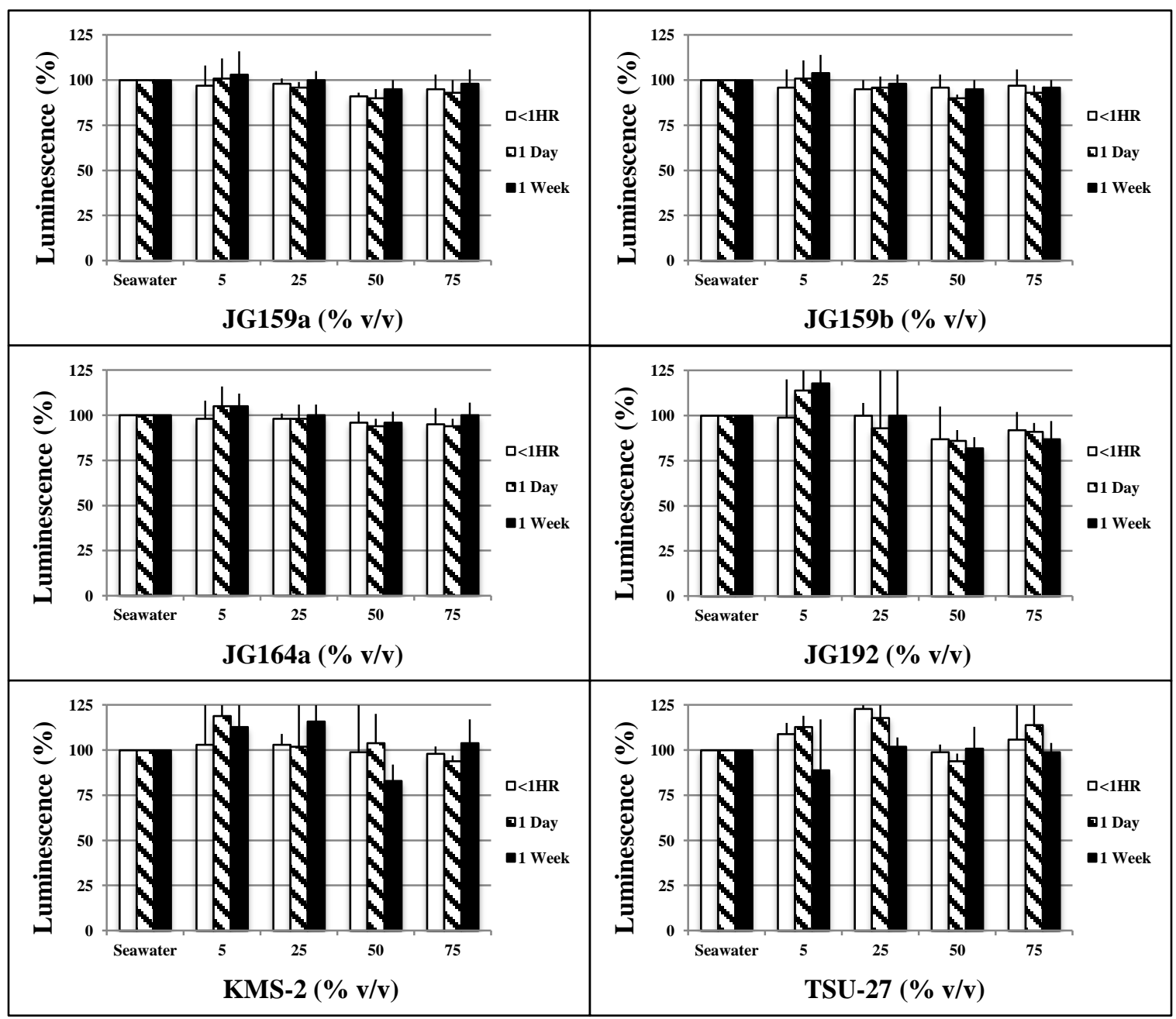



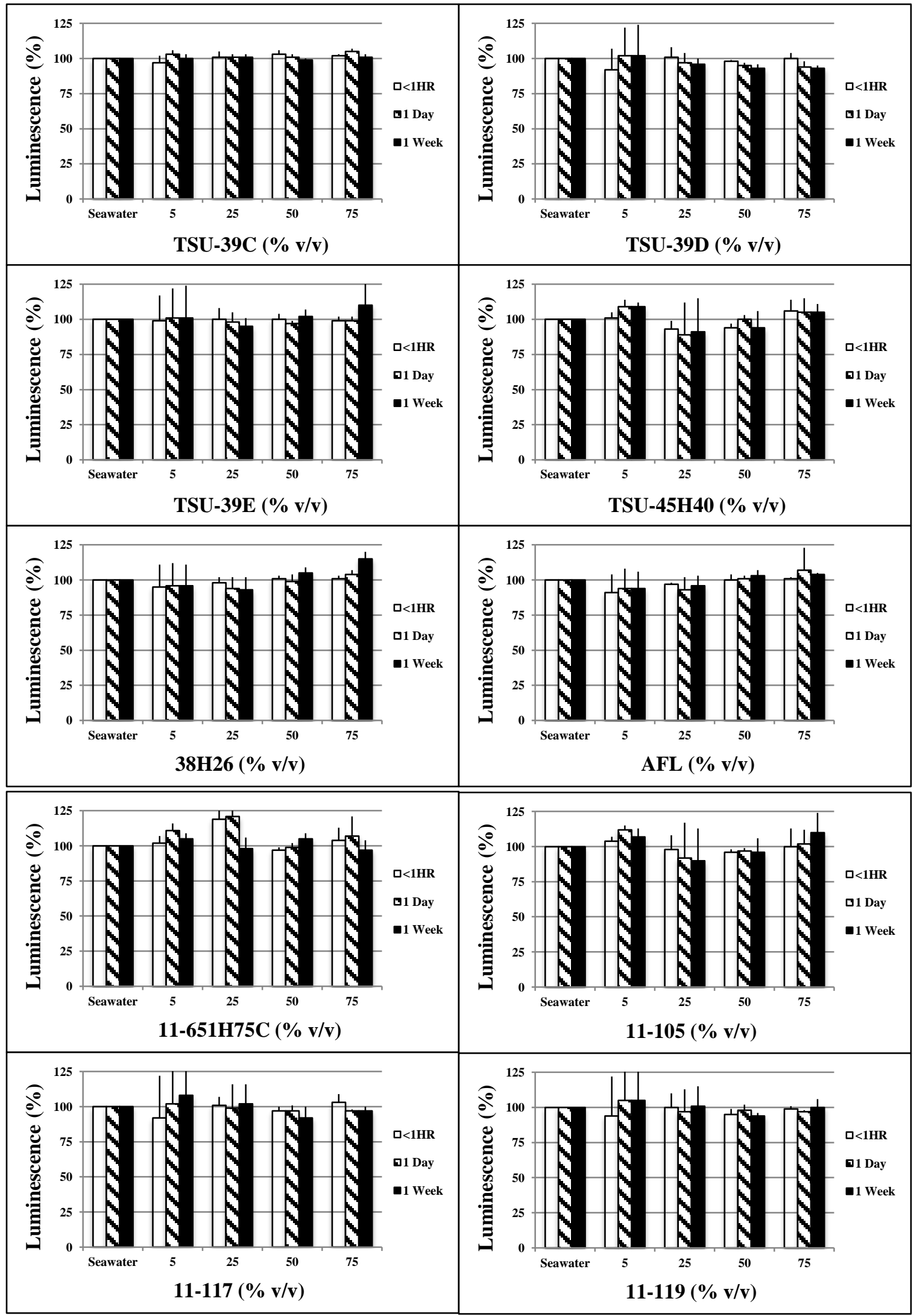

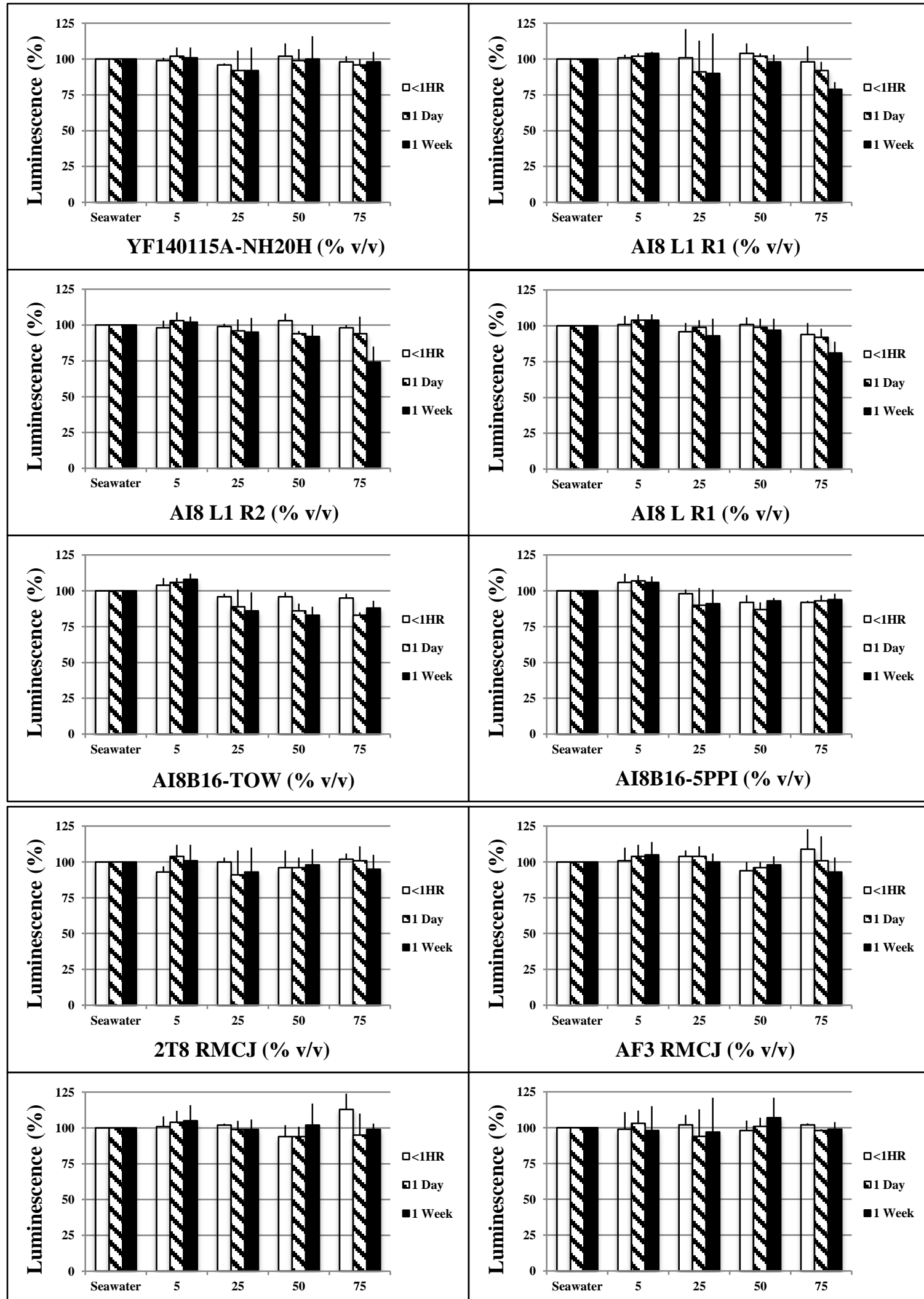

AF8 RMCJ (\% v/v)

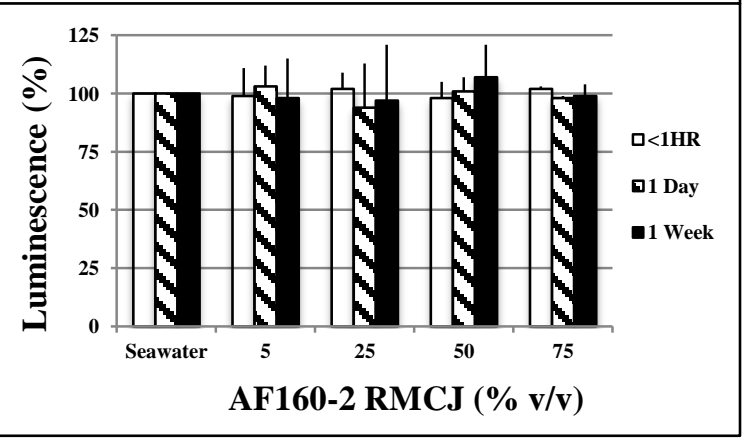



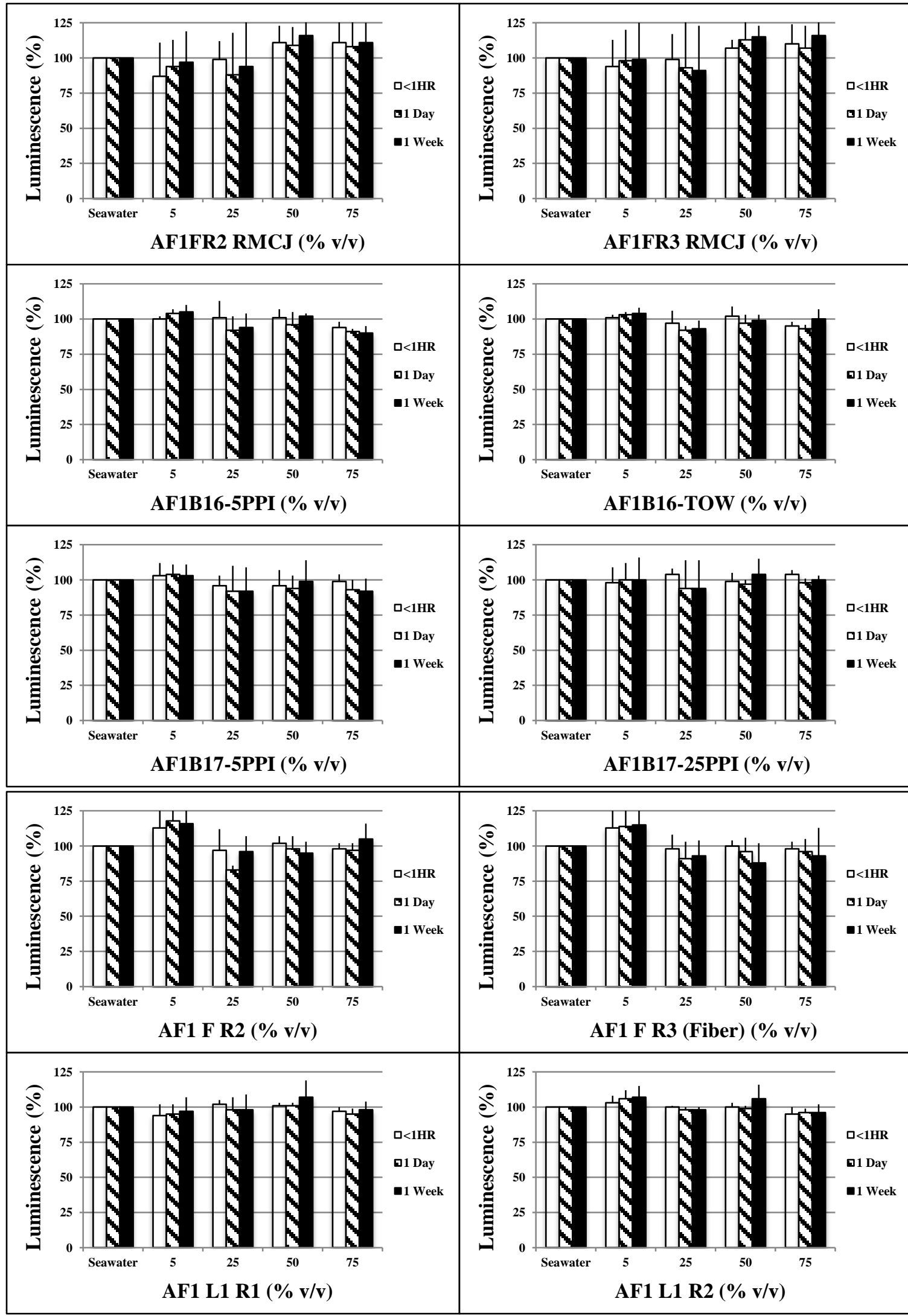

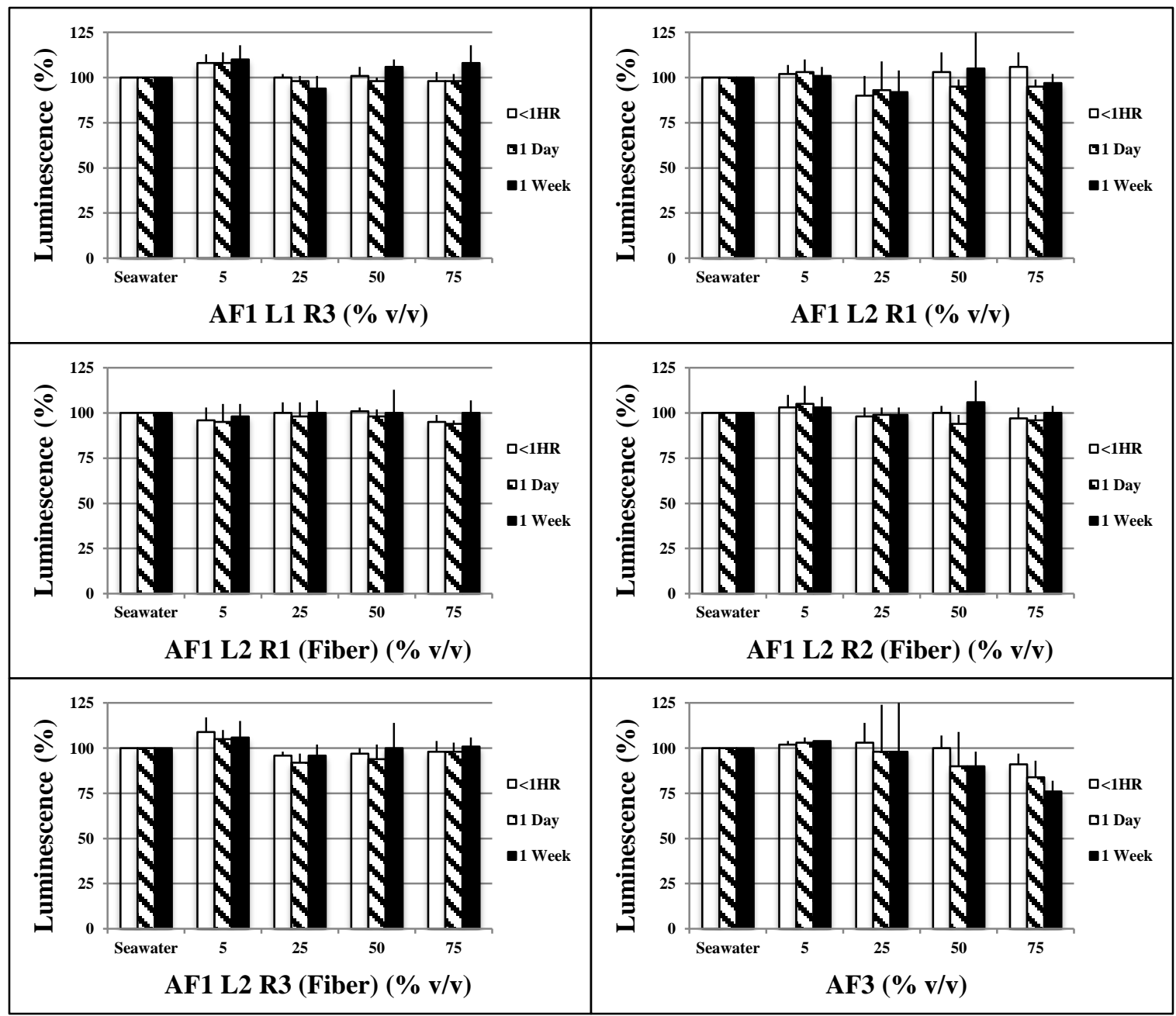

2) The City University of New York (2 adsorbents)

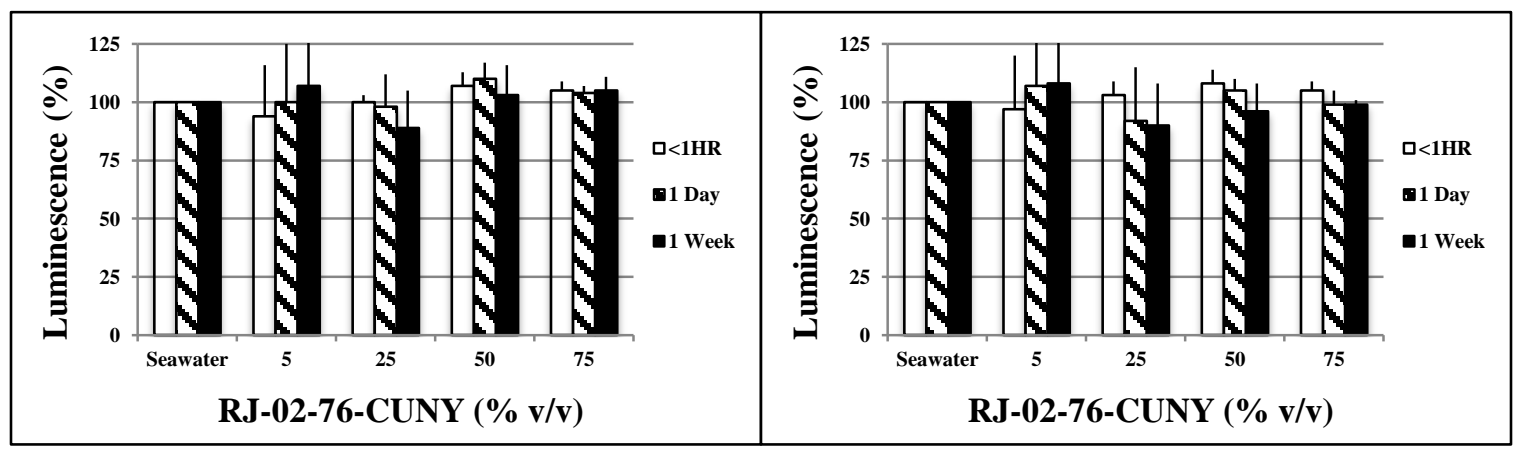


3) University of Maryland (7 adsorbents)
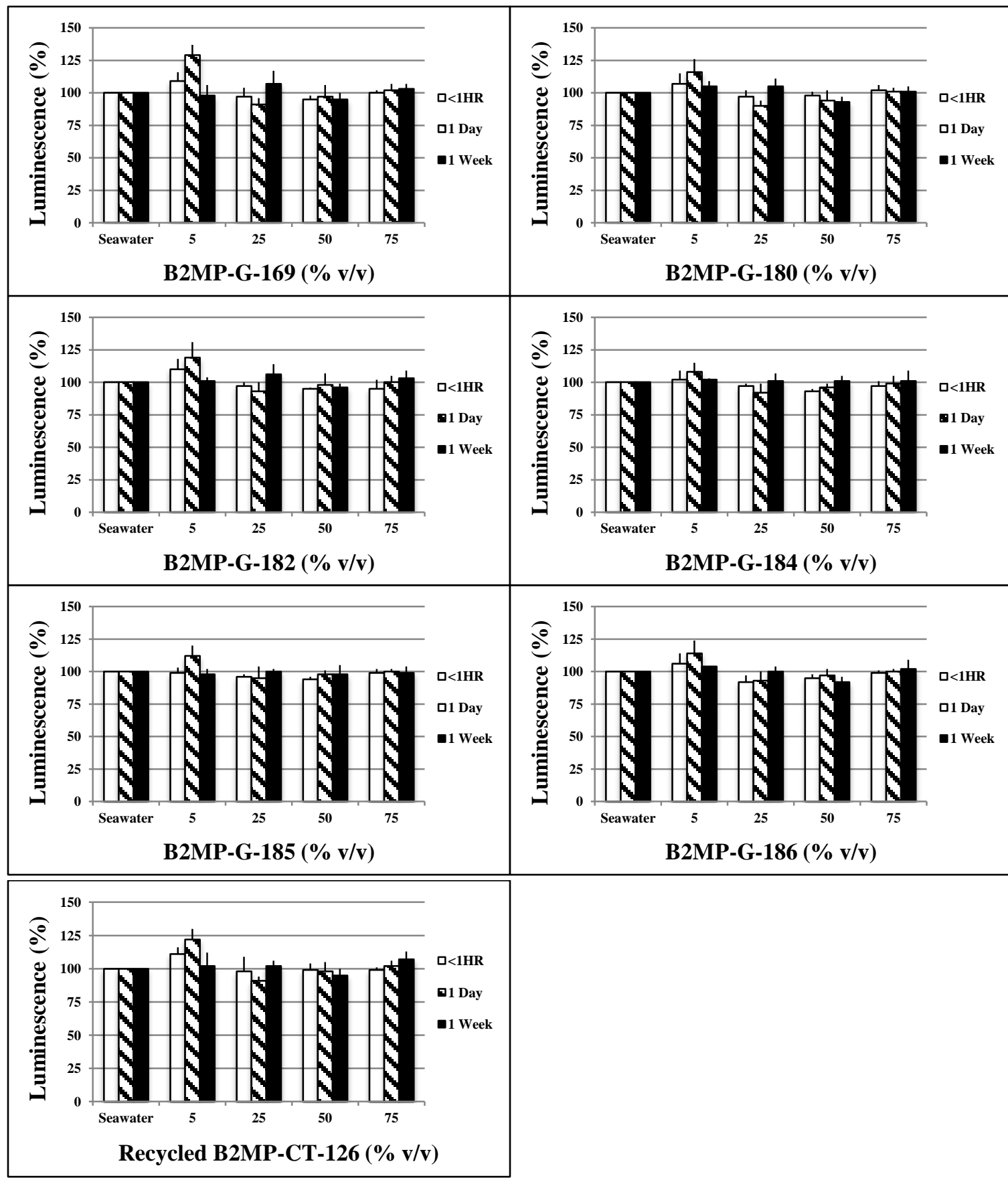
4) Chinese Academy of Science (4 adsorbents)

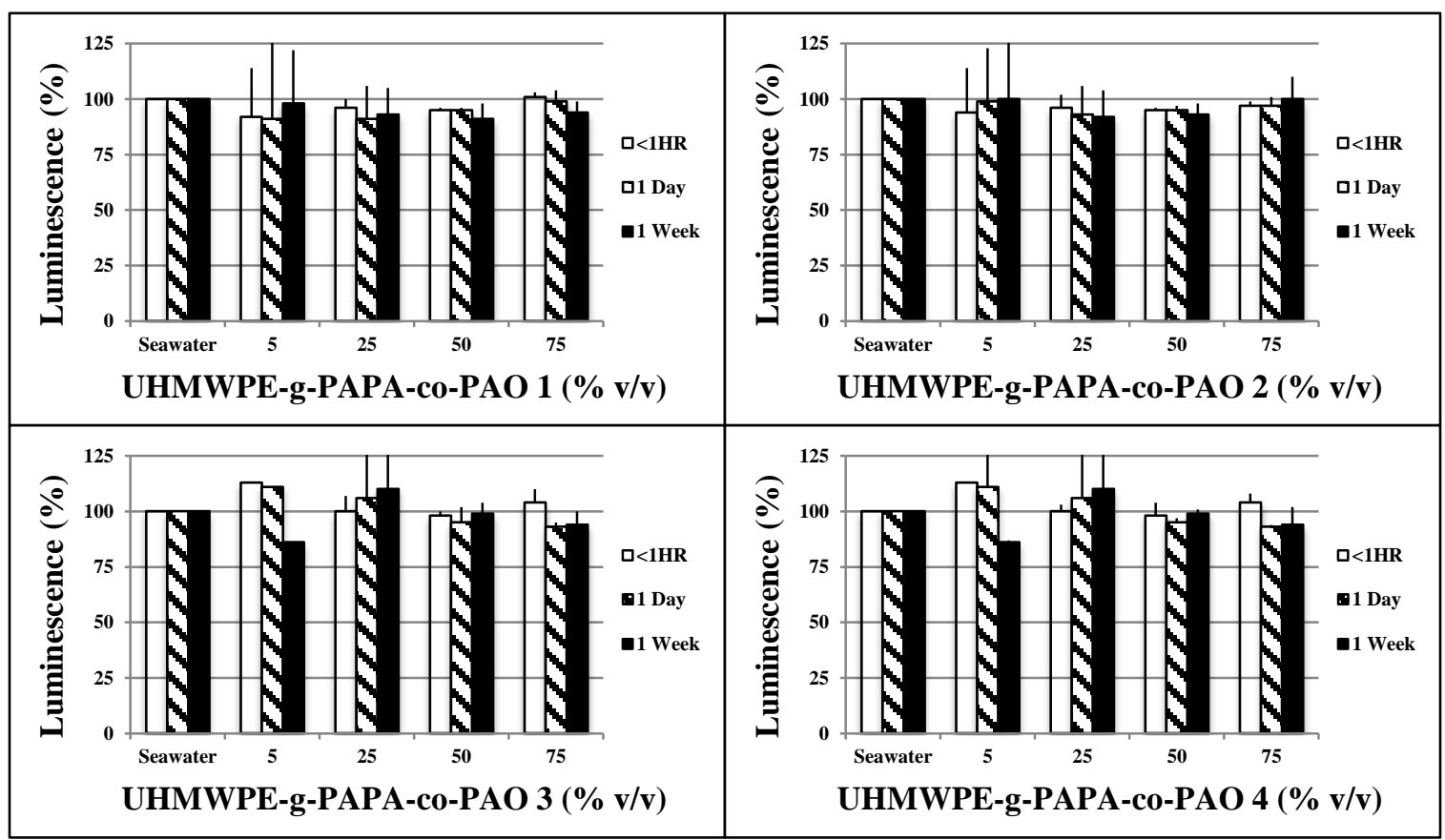




\section{Summary}

We tested the toxicity of direct contact with 10 adsorbent materials at different concentrations. Due to the limited amount of supplied adsorbent samples, our results are preliminary.

\begin{tabular}{|c|c|c|}
\hline Adsorbent & $\mathrm{EC}_{50}$ at & Source \\
\hline $\begin{array}{l}\text { YF130313C } \\
\text { KOH Condition }\end{array}$ & $\begin{array}{c}\text { No } \\
\text { up to } 25 \% \mathrm{v} / \mathrm{v}\end{array}$ & \\
\hline $\begin{array}{c}\text { YF130226C } \\
\text { Copolymer-PAN }\end{array}$ & $\begin{array}{c}\text { Yes } \\
\geq 25 \mathrm{mg} / \mathrm{ml}\end{array}$ & Richard Mayes \\
\hline $\begin{array}{c}\text { CA-4139 } \\
\text { Porous Titanium Dioxide }\end{array}$ & $\begin{array}{c}\text { Yes } \\
\geq 1.1 \mathrm{mg} / \mathrm{ml}\end{array}$ & \multirow{4}{*}{$\begin{array}{l}\text { University of North Carolina } \\
\text { Carter Abney/Lin group }\end{array}$} \\
\hline $\begin{array}{c}\text { CA-4149 } \\
\text { Porous Titanium Phosphate }\end{array}$ & $\begin{array}{l}\text { No } \\
\text { up to } 6.4 \mathrm{mg} / \mathrm{ml}\end{array}$ & \\
\hline $\begin{array}{c}\text { MC-Precursor } \\
\text { Unfunctionalized } \\
\text { Mesoporous Carbon }\end{array}$ & $\begin{array}{l}\text { No } \\
\text { up to } 10 \mathrm{mg} / \mathrm{ml}\end{array}$ & \\
\hline $\begin{array}{c}\text { MC-Phosphate (612) } \\
\text { Phosphoryl-functionalized } \\
\text { Mesoporous Carbon }\end{array}$ & $\begin{array}{c}\text { Yes } \\
\geq 2.5 \mathrm{mg} / \mathrm{ml}\end{array}$ & \\
\hline $\begin{array}{c}\text { UHMWPE-g-PAPA-co-PAO } \\
\text { Chinese functionalized fiber type } 1\end{array}$ & $\begin{array}{c}\text { Yes } \\
\geq 0.625 \mathrm{mg} / \mathrm{ml}\end{array}$ & \multirow{4}{*}{ Chinese Academy of Science } \\
\hline $\begin{array}{l}\text { UHMWPE-g-PAPA-co-PAO } \\
\text { Chinese functionalized fiber type } 2\end{array}$ & $\begin{array}{c}\text { Yes } \\
\geq 0.3125 \mathrm{mg} / \mathrm{ml}\end{array}$ & \\
\hline $\begin{array}{l}\text { UHMWPE-g-PAPA-co-PAO } \\
\text { Chinese functionalized fiber type } 3\end{array}$ & $\begin{array}{l}\text { No } \\
\text { up to } 2.5 \mathrm{mg} / \mathrm{ml}\end{array}$ & \\
\hline $\begin{array}{c}\text { UHMWPE-g-PAPA-co-PAO } \\
\text { Chinese functionalized fiber type } 4\end{array}$ & $\begin{array}{l}\text { No } \\
\text { up to } 2.5 \mathrm{mg} / \mathrm{ml}\end{array}$ & \\
\hline
\end{tabular}


We also tested seawater effluent that came in contact with adsorbent materials in uranium extraction columns. The Microtox ${ }^{\circledR}$ assay was done at multiple concentrations and time points. All 63 samples listed below showed no toxic effects.

\begin{tabular}{|c|c|c|}
\hline Adsorbent & Time Points & Source \\
\hline $38 \mathrm{H} 21$ & 3 Days & \multirow{35}{*}{ Oak Ridge National Laboratory } \\
\hline TSU 20A & 1 Week & \\
\hline Kostas Fiber & 8 Weeks & \\
\hline JG159a & \multirow{32}{*}{$1 \mathrm{Hr}, 1$ Day, \& 1 Week } & \\
\hline JG159b & & \\
\hline JG164a & & \\
\hline JG192 & & \\
\hline KMS-2 & & \\
\hline TSU-27 & & \\
\hline TSU-39C & & \\
\hline TSU-39D & & \\
\hline TSU-39E & & \\
\hline TSU-45H40 & & \\
\hline $38 \mathrm{H} 26$ & & \\
\hline AFL & & \\
\hline $11-651 \mathrm{H} 75 \mathrm{C}$ & & \\
\hline $11-105$ & & \\
\hline $11-117$ & & \\
\hline $11-119$ & & \\
\hline YF140115A-NH20H & & \\
\hline AI8 L1 R1 & & \\
\hline AI8 L1 R2 & & \\
\hline AI8 L2 R1 & & \\
\hline AI8B16-TOW & & \\
\hline AI8B16-5PPI & & \\
\hline 2T8 RMCJ & & \\
\hline AF3 RMCJ & & \\
\hline AF8 RMCJ & & \\
\hline AF160-2 RMCJ & & \\
\hline AF1FR2 RMCJ & & \\
\hline AF1FR3 RMCJ & & \\
\hline AF1B16-5PPI & & \\
\hline AF1B16-TOW & & \\
\hline AF1B17-5PPI & & \\
\hline AF1B17-25PPI & & \\
\hline
\end{tabular}




\begin{tabular}{|c|c|c|}
\hline Adsorbent & Time Points & Source \\
\hline AF1 F R2 & \multirow{10}{*}{$1 \mathrm{Hr}, 1 \mathrm{Day}, \& 1 \mathrm{Week}$} & \multirow{10}{*}{ Oak Ridge National Laboratory } \\
\hline AF1 F R3 & & \\
\hline AF1 L1 R1 & & \\
\hline AF1 L1 R2 & & \\
\hline AF1 L1 R3 & & \\
\hline AF1 L2 R1 & & \\
\hline AF1 L2 R1 (Fiber) & & \\
\hline AF1 L2 R2 (Fiber) & & \\
\hline AF1 L2 R3 (Fiber) & & \\
\hline AF3 & & \\
\hline AO Fiber & \multirow{3}{*}{6 Weeks } & \multirow{3}{*}{ University of Alabama } \\
\hline DA Fiber & & \\
\hline SS Fiber & & \\
\hline RJ-02-76-CUNY & \multirow{2}{*}{$1 \mathrm{Hr}, 1$ Day, \& 1 Week } & \multirow{2}{*}{$\begin{array}{c}\text { The City University } \\
\text { New York }\end{array}$} \\
\hline RJ-03-66-CUNY & & \\
\hline B2MP-G-169 & \multirow{7}{*}{$1 \mathrm{Hr}, 1$ Day, \& 1 Week } & \multirow{7}{*}{ University of Maryland } \\
\hline B2MP-G-180 & & \\
\hline B2MP-G-182 & & \\
\hline B2MP-G-184 & & \\
\hline B2MP-G-185 & & \\
\hline B2MP-G-186 & & \\
\hline Recycled B2MP-CT-126 & & \\
\hline Japan 2010 & 3 Days & Japan Atomic Energy Agency \\
\hline Chinese Fiber \#2 & 3 Days & \multirow{5}{*}{ Chinese Academy of Science } \\
\hline UHMWPE-g-PAPA-co-PAO 1 & \multirow{4}{*}{$1 \mathrm{Hr}, 1 \mathrm{Day}, \& 1$ Week } & \\
\hline UHMWPE-g-PAPA-co-PAO 2 & & \\
\hline UHMWPE-g-PAPA-co-PAO 3 & & \\
\hline UHMWPE-g-PAPA-co-PAO 4 & & \\
\hline
\end{tabular}

\section{Conclusion}

Uranium adsorbent materials had little or no toxicity even when assayed with direct contact at ppthousand levels. It is important to note that these adsorbent materials will be exposed in the marine environment at pp-billion or lower levels. Hence these results provide preliminary evidence that uranium extraction from seawater could be performed with minimal impact to marine fauna. We conclude that the adsorbent materials used to extract uranium from seawater are relatively non-toxic and likely to have minimal contact with marine organisms on a large scale 


\section{References}

1. Girotti SL, Bolelli L, Roda A, Gentilomi G, \& Musiani M (2002) Improved detection of toxic checmicals using bioluminescent bacteria. Analytical Chimica Acta 473:113-120.

2. Fulladosa E, Murat JC, \& Villaescusa I (2005) Study on the toxicity of binary equitoxic mixtures of metals using the luminescent bacteria Vibrio fischeri as a biological target. Chemosphere 58(5):551-557.

3. Tsiridis V, et al. (2006) Interactive toxic effects of heavy metals and humic acids on Vibrio fischeri. Ecotoxicology and environmental safety 63(1):158-167.

4. Backhaus T, Scholze M, \& Grimme LH (2000) The single substance and mixture toxicity of quinolones to the bioluminescent bacterium Vibrio fischeri. Aquat Toxicol 49(1-2):49-61.

5. Lei L \& Aoyama I (2010) Effect-directed investigation and interactive effect of organic toxicants in landfill leachates combining Microtox test with RP-HPLC fractionation and GC/MS analysis. Ecotoxicology 19(7):1268-1276.

6. De Zwart D \& Sloof W (1983) The Microtox as an alternative assay in the acute toxicity assessment of water pollutants. Aquatic Toxicology 4:129-138.

7. Chang JC, Taylor PB, \& Leach FR (1981) Use of the Microtox assay system for environmental samples. Bulletin of Environmental Contamination and Toxicology 26:150-156.

8. Ankley GT, Hoke RA, Giesy JP, \& Winger PV (1989) Evaluation of the toxicity of marine sediments and dredge spoils with the Microtox bioassay. Chemosphere 18:2069-2075.

9. Anonymous (2003) ETV Joint Verification Statement. (U.S. Environmental Protection Agenecy and Battelle).

10. Station USGSBRDMER (1998) Toxicity Testing of Sediment from delaware Bay and surrounding Areas. National Oceanic and Atmospheric Administration Office of Ocean Resources Conservation Assessment.

11. Parvez S, Venkataraman C, \& Mukherji S (2006) A review on advantages of implementing luminescence inhibition test (Vibrio fischeri) for acute toxicity prediction of chemicals. Environment international 32(2):265-268.

12. Dutka BJ \& Kwan KK (1982) Application of four bacterial screening procedures to assess changes in the toxicity of chemicals in mixtures. Environmental Pollution 29:125-134. 


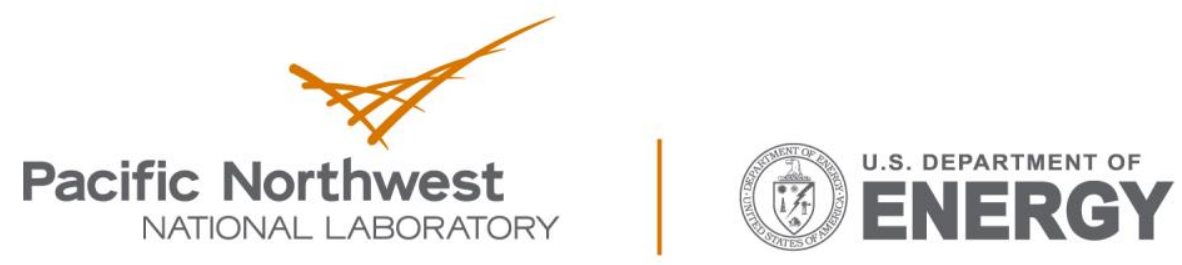

Proudly Operated by Battelle Since 1965

902 Battelle Boulevard

P.O. Box 999

Richland, WA 99352

1-888-375-PNNL (7665)

www.pnnl.gov 